The University of Maine

\title{
DigitalCommons@UMaine
}

Marine Sciences Faculty Scholarship

School of Marine Sciences

$8-1-2001$

\section{Simulation of the Impact of Dams and Fishing Weirs on Reproductive Potential of Silver-Phase American Eels in the Kennebec River Basin, Maine}

James McCleave

University of Maine - Main, mccleave@maine.edu

Follow this and additional works at: https://digitalcommons.library.umaine.edu/sms_facpub

\section{Repository Citation}

McCleave, James, "Simulation of the Impact of Dams and Fishing Weirs on Reproductive Potential of Silver-Phase American Eels in the Kennebec River Basin, Maine" (2001). Marine Sciences Faculty Scholarship. 121.

https://digitalcommons.library.umaine.edu/sms_facpub/121 


\title{
Simulation of the Impact of Dams and Fishing Weirs on Reproductive Potential of Silver-Phase American Eels in the Kennebec River Basin, Maine
}

\author{
JAMES D. MCCleave* \\ School of Marine Sciences, University of Maine, \\ 5741 Libby Hall, Orono, Maine 04469-5741, USA
}

\begin{abstract}
I modeled the cumulative impact of hydroelectric projects with and without commercial fishing weirs and water-control dams on the production, survival to the sea, and potential fecundity of migrating female silver-phase American eels Anguilla rostrata in the Kennebec River basin, Maine. This river basin has 22 hydroelectric projects, 73 water-control dams, and 15 commercial fishing weir sites. The modeled area included an $8,324 \mathrm{~km}^{2}$ segment of the drainage area between Merrymeeting Bay and the upper limit of American eel distribution in the basin. One set of inputs (assumed or real values) concerned population structure (i.e., population density and sex ratio changes throughout the basin, female length-class distribution, and drainage area between dams). Another set concerned factors influencing survival and potential fecundity of migrating American eels (i.e., pathway sequences through projects, survival rate per project by length-class, and length-fecundity relationship). Under baseline conditions about 402,400 simulated silver female American eels would be produced annually; reductions in their numbers due to dams and weirs would reduce the realized fecundity (i.e., the number of eggs produced by all females that survived the migration). Without weirs or water-control dams, about $63 \%$ of the simulated silverphase American eels survived their freshwater spawning migration run to the sea when the survival rate at each hydroelectric dam was $90 \% ; 40 \%$ survived at $80 \%$ survival per dam, and $18 \%$ survived at $60 \%$ survival per dam. Removing the lowermost hydroelectric dam on the Kennebec River increased survival by $6.0-7.6 \%$ for the basin. The efficient commercial weirs reduced survival to the sea to $69-76 \%$ of what it would have been without weirs, regardless of survival rates at hydroelectric dams. Water-control dams had little impact on production in this basin because most were located in the upper reaches of tributaries. Sensitivity analysis led to the conclusion that small changes in population density and female length distribution had greater effects on survival and realized fecundity than similar changes in turbine survival rate. The latter became more important as turbine survival rate decreased. Therefore, it might be more fruitful to determine population distribution in basins of interest than to determine mortality rate at each hydroelectric project.
\end{abstract}

Recently in Maine, commercial fishing effort for the American eel Anguilla rostrata, has increased dramatically for their unpigmented elvers, has increased for their yellow phase, and has held steady for their silver phase. Elvers, the early juveniles, are harvested with fyke nets in tidal waters as they ascend from the sea into freshwaters. Yellowphase, older juveniles, are harvested with baited traps in estuaries, lakes, and rivers. Silver-phase eels, the maturing adults, are harvested with interception gear (weirs, fyke nets) as they move down rivers on their spawning migration to the Sargasso Sea.

Juvenile American eels may spend several years gradually migrating up river basins. Silver eels migrate quickly downstream to the sea during autumn. Thus, both juveniles and adults contend with

* Corresponding author: mccleave@maine.edu

Received June 28, 2000; accepted January 8, 2001 hydroelectric and water-control dams, which hinder both upstream and downstream passage (Anonymous 1999). Conservation concerns have forced emphasis on the importance of eel passage, especially downstream passage, in re-licensing of current hydroelectric projects. Tensions have heightened among stakeholder groups, with eel harvesters, especially harvesters of silver eels, having a tendency to consider hydroelectric projects as the principal sources of anthropogenic mortality.

Because the American eel is a semelparous species (spawns once and dies), all prespawning natural and anthropogenic mortality occurs before any reproduction, which is not easily mitigated by typical fishery management practices. Female silver eels average about age 16 in Maine (Oliveira and McCleave, 2000), so those that migrate to sea in a given year have escaped mortality for a long time. Thus, it is important to understand the interactive nature of life history traits and various 
sources of mortality. This study focuses on the cumulative impact of hydroelectric dams on reproductive potential of female American eels within a river basin. The reproductive potential of females in any river affects the population as a whole because genetic evidence shows that the American eel is a panmictic species (Avise et al. 1986). Offspring of a given mating apparently may be distributed anywhere in the geographic range from northern South America to Greenland.

The main objective originally was to combine estimates of American eel population structure, female eel fecundity, and mortality at various hydroelectric projects in a model to estimate the cumulative impact of hydroelectric operations on annual reproductive potential of female silver eels migrating from a selected river basin. However, the literature revealed extreme variability in estimates of turbine-induced mortality of anguillids (see below) and a paucity of estimates of anguillid population structure, especially silver eel production. Therefore, modeling was used as a learning tool (Johnson 1995) to identify factors affecting the reproductive potential of female silver American eels. The main objective was to combine assumptions about eel populations and various daminduced mortality scenarios with knowledge of length-fecundity relations (Barbin and McCleave 1997) and thereby estimate the impact of hydroelectric projects on reproductive potential. Secondary objectives were to estimate the impact of water-control dams and the superimposed mortality of commercial weir fisheries for silver eels on reproductive potential. A simple, deterministic model was developed based on the Kennebec River basin in Maine, which is easily applicable to other drainage basins. As a tool, the model provided insight into research needs for determining the actual impacts of multiple influences on production and reproductive potential in river basins.

\section{Mortality of Anguillids in Turbines}

The sparse literature on mortality of anguillids during passage through hydroelectric-generating turbines, although often conflicting, indicates considerable variability in mortality during turbine passage. Turbines for low- and medium-head projects are principally of three types having many configurations: Francis, Kaplan, and propellor (Fritz 1984; Montén 1985). All three types, have rotating blades that are entirely immersed in water. Francis turbines typically have 10-20 fixed-angle blades, whereas Kaplan turbines typically have 4 8 adjustable-angle blades. Adjustable blade angles means that the spacings through which eels have to pass are variable, depending on operating conditions. Propellor turbines have some characteristics of both other types but do have fixed-angle blades. Most of the turbines on the Kennebec River basin are Francis type, but Kaplan and propellor turbines are present.

Montén (1985) reviewed literature to the early 1970s on fish injury and mortality during turbine passage. In his summary of 19 European eel $A n$ guilla anguilla experiments conducted at eight power stations in Sweden, he reported injury rates of $40-100 \%$ in $73-\mathrm{cm}$ eels passing through Kaplan turbines under various operating conditions. In 3 of these experiments, $63-81 \%$ of $57-\mathrm{cm}$ eels were injured. Most of these injury percentages probably resulted in mortality because the "injured" category was for severe injuries. Rates of injury decreased with increased blade spacing in a particular turbine. Similarly, Berg (1986) reported rates of eel mortality ("lethal injuries") of $15-50 \%$ in a Kaplan turbine operated with different blade angles.

Montén (1985) also reported injury rates for 5052-cm European eels of 9, 65, and 100\% for one small Francis turbine (82-cm-diameter runner) operated under generator load conditions of 61,80 , and $100 \%$, respectively. Increased load was associated with increased flow of water. In direct contrast, Hadderingh and Bakker (1998) reported mortality rates of similarly sized eels of 23, 10 , and $6 \%$ for a larger Kaplan turbine as flow through the turbine increased. American eels averaging 86 $\mathrm{cm}$ sustained $9 \%$ mortality in a small Francis turbine (RMC 1995), but the severity of some injuries may have been underestimated.

At a large power station on the St. Lawrence River (Complexe Beauharnois), mortality rates of American eels averaging $88 \mathrm{~cm}$ were estimated at $16 \%$ for a Francis turbine and at $24 \%$ for a propellor turbine (Desrochers 1995). Similarly, mortality of eels averaging $102 \mathrm{~cm}$ was estimated at about $26.5 \%$ for a propellor turbine at another large project on the St. Lawrence (Robert Moses Power Dam; Normandeau Associates and Skalski 1998). Richkus and Whalen (1999) also reviewed eel mortality from turbine entrainment.

Although mortality data are variable, several points of importance emerged from the literature. (1) Mortality rate is positively related to eel length (Travade and Larinier 1992). This puts female eels at particular risk because they are much larger than males (Helfman et al. 1987; Krueger and Oliveira 1997; Oliveira and McCleave 2000). (2) Mortality 
rate is inversely proportional to the spacing between blades in a particular turbine (Travade and Larinier 1992), a characteristic that is variable for Kaplan turbines. (3) Mortality rate is dependent not only on turbine and dam characteristics but also on operating conditions, such as flow and relation to percentage and efficiency of generating capacity (Montén 1985; Hadderingh and Bakker 1998). Mortality rates are not only site-specific but time-specific as well. (4) Eels that are injured at one facility may be at increased risk of mortality at the next facility downstream. (5) Estimates of survival from all studies are overestimates of potential spawning success because of the short-term nature of the studies. To spawn successfully, eels must migrate thousands of kilometers, during which time sublethal injuries can manifest themselves.

\section{Study Area}

The Kennebec River is the second largest drainage basin in Maine. This study considered only that portion of the basin above Merrymeeting Bay (i.e., above $44^{\circ} 00.1^{\prime} \mathrm{N}, 69^{\circ} 49.4^{\prime} \mathrm{W}$ ). The area from Merrymeeting Bay to the open sea was excluded because it is tidally complex and receives water from sources outside the Kennebec drainage. The drainage area is $15,263 \mathrm{~km}^{2}$ above Merrymeeting Bay, and the drainage area is $8,324 \mathrm{~km}^{2}$ between Merrymeeting Bay and Wyman Dam, the upper limit of American eel distribution. Below Wyman Dam there are lakes and ponds having a total surface area exceeding $270 \mathrm{~km}^{2}$.

There were 22 dams with hydroelectric generating stations on the main stem and tributaries of the Kennebec River between Merrymeeting Bay and Wyman Dam in recent history (Figure 1). Their mean dam height exceeded $9 \mathrm{~m}$. The generating stations range from minuscule (about 25 $\mathrm{kW}$ at Starks) to substantial (about 17.5 MW at Hydrokennebec), with one to nine turbines present at each. As of 1999, one of the dams (Edwards) had been removed, and one of the stations (New Mills) was not generating electricity, but they were considered to be generating in most situations in this paper (i.e., representing recent historical conditions in the basin). Drainage areas between successive hydroelectric dams ranged from 2.6 to $1,417 \mathrm{~km}^{2}$ (Table 1; calculated mostly from Fontaine 1979). There were approximately 73 waterlevel control dams in the basin (Anonymous 1994), but determining the actual number present would require a complete survey of the drainage. Most are high in the tributaries of the drainage. Twelve water-control dams visited by the author had an estimated mean height less than $1.5 \mathrm{~m}$.

In 1999, there were 15 weir sites licensed for commercial harvest of silver American eels in the study area, all on tributaries to the main stem of the Kennebec River, 13 of which were above at least one hydroelectric dam. Depending on the particular site, these weirs may have blocked the entire stream or a portion of it during the autumn fishing season. Water-level control dams and weirs were not considered to be present, except in the specific simulations of their effects.

\section{Methods}

Development of the model.-The number of female silver American eels successfully migrating from a river basin to the sea depends upon factors influencing the production of females in different parts of the basin and factors influencing survival between those parts and the sea. The first set of factors exerts influence over many years but was represented in the model as the cumulative situation at the onset of the seaward spawning migration. The second set exerts influence over a few weeks and was represented in the model as sequential size-dependent survival fractions at each obstacle to migration (dam or weir). The simulation model considered only female eels for two reasons: (1) because of their larger size, females are subject to lower survival in turbines than are males, and (2) only females produce eggs and thus are the determinants of population fecundity.

The model, written in FORTRAN, accepted two types of input, one about American eel population structure within the drainage basin, and the other about distribution of hydroelectric turbines (and weirs) and their associated eel survival rates. Here, population structure meant annual production and length distribution of female silver eels. Factors (variables) in the model affecting production were (1) population density of silver eels at the mouth of the drainage, (2) sex ratio of silver eels at mouth of drainage, (3) rate of decrease in population density as a function of position upstream, (4) rate of increase in proportion of females as a function of position upstream, (5) female length-frequency distribution, and (6) drainage area between each pair of obstacles along a path. Values for these variables were estimated from the literature or they were assumed. Values for factors 3 and 4 were incremented at each hydroelectric dam for ease of calculation, though probably only factor 3 was directly influenced by the dams (through hindrance to upstream passage some years earlier). In model 


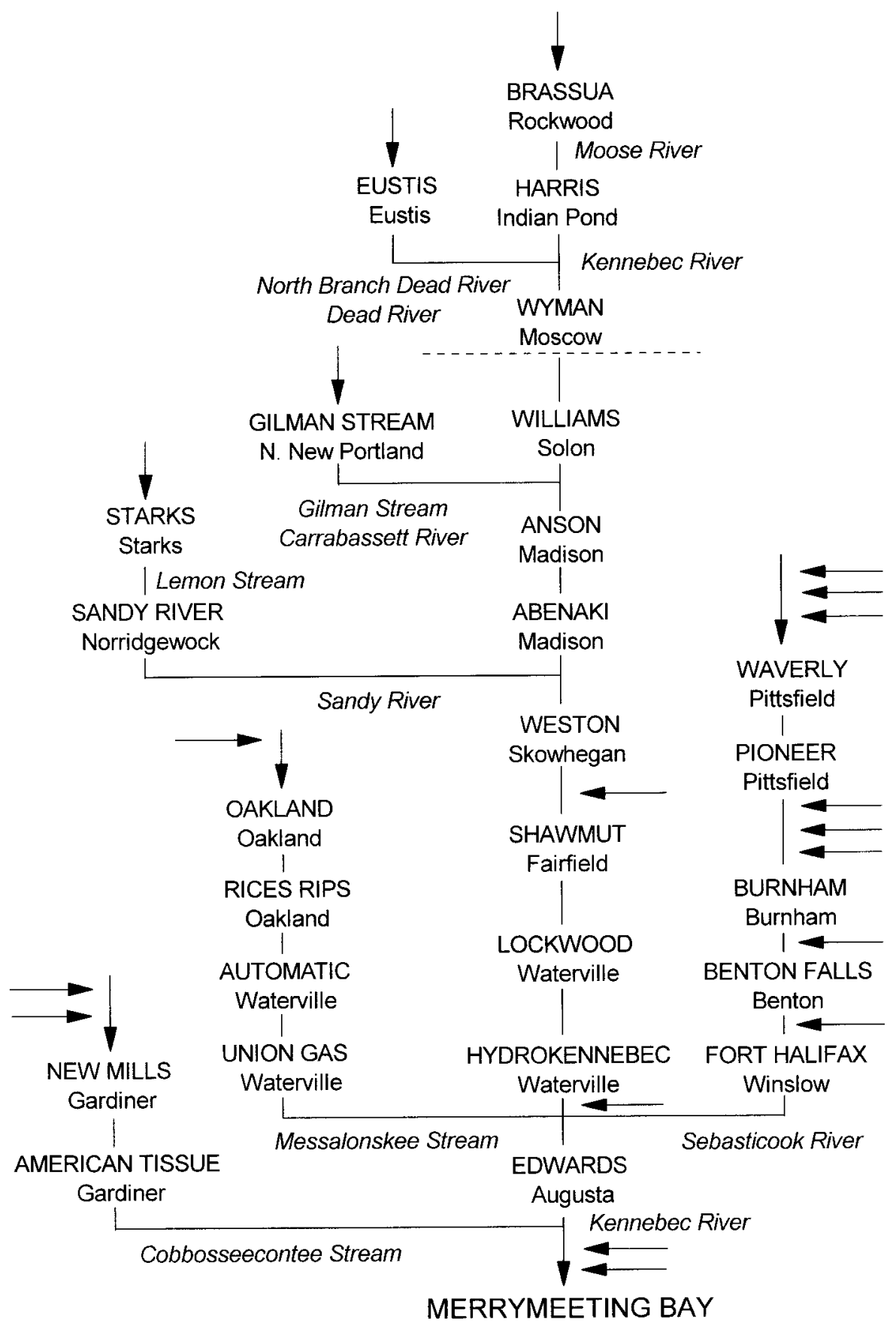

Figure 1.-Schematic diagram of the Kennebec River basin above Merrymeeting Bay, Maine, showing hydroelectric projects (all capitals), the closest municipality to the project, and names of streams on which the projects are located (in italics). Streams without hydroelectric dams are not shown but are included in the model. The downward-pointing arrows indicate water flow; the horizontal arrows indicate where commercial American eel weirs are located on the named stream or a tributary; and the dashed line indicates the upstream limit of American eel distribution. The complexity of the basin precludes a map showing the location of hydroelectric dams, watercontrol dams, and commercial fishing weirs. 
TABLE 1.-Drainage areas and number of commercial fishing weirs for American eels between successive hydroelectric dams (Figure 1) in the Kennebec River basin, Maine. Lake area is the percentage of a drainage surface area composed of lakes and ponds.

\begin{tabular}{lrrc}
\hline \multicolumn{1}{c}{ Dam } & $\begin{array}{r}\text { Area above } \\
\left(\mathrm{km}^{2}\right)^{\mathrm{a}}\end{array}$ & $\begin{array}{c}\text { Lake area } \\
(\%)\end{array}$ & $\begin{array}{c}\text { Number } \\
\text { of weirs }\end{array}$ \\
\hline Williams & 261.6 & 1.5 & \\
Gilman Stream & 243.5 & 0.4 & \\
Anson & $1,124.1$ & 0.9 & \\
Abenaki & 2.6 & $<0.1$ & \\
Starks & 80.3 & $<0.1$ & \\
Sandy River & $1,416.7$ & 0.9 & \\
Weston & 173.5 & $<0.1$ & \\
Shawmut & 823.6 & 1.2 & 1 \\
Lockwood & 31.1 & $<0.1$ & \\
Hydrokennebec & 10.4 & $<0.1$ & \\
Oakland & 461.0 & 17.4 & 1 \\
Rices Rips & 18.1 & $<0.1$ & \\
Automatic & 51.8 & $<0.1$ & \\
Union Gas & 5.2 & $<0.1$ & \\
Waverly & 805.5 & 3.2 & 3 \\
Pioneer & 5.2 & $<0.1$ & \\
Burnham & 665.6 & 4.3 & 3 \\
Benton Falls & 756.3 & 1.8 & 1 \\
Fort Halifax & 217.6 & 8.6 & 1 \\
Edwards & 134.7 & 8.8 & 1 \\
New Mills & 559.4 & 9.5 & 2 \\
American Tissue & 2.6 & $<0.1$ & \\
Merrymeeting Bay & 474.0 & 1.0 & 2 \\
\hline Above & & & \\
\hline
\end{tabular}

a Above the listed location, including tributaries, and below the next dam upstream or to the head of the drainage.

scenarios considering the effect of water-control structures, values for factor 3 were incremented at each water-control dam also.

Factors affecting survival at obstacles to seaward migration were (1) pathways, (2) number of obstacles below each drainage area, (3) assumed base survival rate at each obstacle, and (4) survival increments per length-class. Pathways were the sequences of particular obstacles between each drainage area and the lower end of the model domain. Obstacles were primarily hydroelectric projects but included weirs for one specific simulation. All hydroelectric dams were assumed to impart the same rate of survival, although the model was formulated to allow rates to differ from obstacle to obstacle. All weirs, when included, were also assumed to impart the same rate of survival. Water-control dams, when included in a simulation, were assumed not to affect survival. Values for pathways, drainage areas, and number of obstacles were actual for the Kennebec River basin. Survival rates were, of course, key variables in different simulation runs of the model. Some natural mortality occurs during seaward migration, but this was not incorporated into the model because it was expected to be much lower than tur- bine mortality for female silver eels (De Leo and Gatto 1995).

The simulation model of production, mortality, and survival presented here was deterministic; that is, probability distributions and random variability were not assigned to factors in the model. Stochastic or dynamic models would have added unwarranted complexity (Hilborn and Mangel 1997) and produced results more difficult to interpret, given the uncertainty about many of the variables in the model.

The model simulated the production of female silver American eels by length-class for each area between pairs of obstacles and accumulated the totals for the river system as a whole. Each area between obstacles was counted only once as branches of the drainage "tree" came together. The model then calculated survival by decreasing the production by length-class from each area by the survival factor for each obstacle between that area and the sea; it also accumulated the totals for the river system as a whole.

Finally, the model calculated potential population fecundity (the number of eggs that would have been produced if all females survived the simulated migration) and realized fecundity (the number of eggs produced by all females that survived the migration). Calculation of fecundity by lengthclass was based on the exponential relationship between length and fecundity for American eels (Barbin and McCleave 1997):

$$
\log _{10} F=1.2601+2.9642 \cdot \log _{10} L,
$$

where $F$ is female fecundity (total number of eggs in an individual female), and $L$ is the total length of the female $(\mathrm{cm})$.

Sensitivity analysis.-Sensitivity analysis was performed on the most important model simulations, which allowed comparison of the relative importance of a small change in each variable in the model (Burgman et al. 1993; Heppel et al. 1996). In the analyses, the value of each variable was increased and decreased by $5 \%$, one variable at a time, and changes in simulated production and survival of American eels and realized fecundity were calculated. Sensitivity values, $S$, were dimensionless numbers calculated as

$$
S=\left(O_{v \times 1.05}-O_{v \times 0.95}\right)\left(O_{v} \times 0.1\right)^{-1},
$$

where $O$ was the output (production or survival) for each $v$, which was the condition of each variable (i.e., original value, value increased by $5 \%$, and value decreased by $5 \%$ ). A positive value of 
$S$ meant that a small increase in the value of a given variable resulted in an increase in population output. A negative value of $S$ meant that a small increase in the value of the variable resulted in a decrease in population output.

Baseline conditions.-For most sets of simulations addressing a particular question, three rates of survival of a central female length-class at each hydroelectric dam were compared: 90, 80, and $60 \%$. These rates of survival per dam were probably higher than actual rates of survival per turbine, at least under some operating conditions. However, they allowed for the fact that not all eels may go through a turbine when passing a dam. Other baseline conditions were

(1) annual production of silver eels at bottom of basin $=1 /$ ha of drainage area;

(2) production decreased by $5 \%$ above each hydroelectric dam;(3) sex ratio at bottom of basin = $1: 1$

(4) proportion of females increased by $2.5 \%$ above each hydroelectric dam;

(5) five length-classes of females, centered on equal increments over a $30-\mathrm{cm}$ spread, namely, 50 , $57.5,65,72.5$, and $80 \mathrm{~cm}$;

(6) $40 \%$ of production occurred in central length-class, $20 \%$ in each adjacent class, and $10 \%$ in each end class;

(7) mortality rate for central length-class per hydroelectric dam $=10,20$, or $40 \%$ (survival rate $=1-$ mortality rate);

(8) mortality rate for five length-classes from smallest to largest $=0.8,0.9,1.0,1.1,1.2$ times that of the central length-class (survival rate $=1$ - mortality rate);

(9) equal rate of survival at all hydroelectric dams;

(10) all 22 hydroelectric dam sites have operating turbines;

(11) no water-control dams present;

(12) no weirs for silver eels present.

There is little literature on total annual production of silver anguillid eels by size and sex within river basins, although many populations have been sampled for other characteristics. Vøllestad and Jonsson (1988) estimated production of silver female European eels at about $0.5 /$ ha of drainage area in a Norwegian river, which is probably conservative because they believed the river was a below-average producer. My baseline condition for production above was based on their estimate. The decrease in production of American eels and the increase in proportion of females above each hydroelectric dam are assumed values. However,

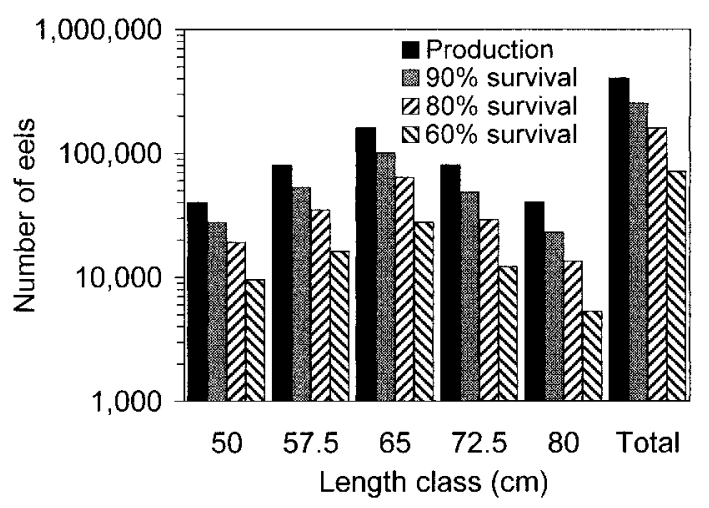

Figure 2.-Modeled production (100\% survival) of female silver American eels and their survival by lengthclass and overall at three rates of survival at dams in the Kennebec River basin.

decreased production reflects a combination of hindrance to upstream migration and a natural trend. The increase in proportion of females is probably a natural trend. Smogor et al. (1995) found that the density of small- and medium-sized American eels, the latter including maturing males, decreased with distance above the mouths of Virginia rivers. The density of large eels, probably mostly females, did not decrease upstream.

\section{Results}

\section{Cumulative Effects of 22 Hydroelectric Projects}

Approximately 402,400 simulated silver female American eels would be produced annually in the Kennebec River basin given the baseline conditions (i.e., reflecting the hindering effect of hydroelectric dams on upstream passage of juveniles). Obviously, survival through the entire ba$\sin$, as a fraction of this production, decreased with increasing size of eels and decreased with decreasing dam survival (Figure 2).

Over the length-classes combined, about $63 \%$ of the simulated American eels produced in the basin survived to exit into the Gulf of Maine at a mean survival rate of $90 \%$ per dam, $40 \%$ survived at $80 \%$ survival per dam, and only $18 \%$ survived at $60 \%$ survival per dam (Table 2 ). Survival rates among length-classes varied because of built-in mortality increments for different length-classes. For example, at the mean survival rate of $80 \%$ per dam, survival of the length-classes ranged from $48 \%$ for the smallest length-class to $33 \%$ for the largest.

Realized population fecundity for all lengthclasses combined was lower than American eel 
TABLE 2.-Simulated production of silver-phase female American eels and their potential population fecundity in the Kennebec River basin with 22 hydroelectric dams in operation; also, the percentages of eels and eggs surviving at three rates of survival of eels at each hydroelectric dam passed during the seaward migration. Survival percentages are equal for eels and fecundity within length-classes but differ when length-classes are combined.

\begin{tabular}{|c|c|c|c|c|c|c|c|}
\hline \multirow[b]{2}{*}{ Variable } & \multicolumn{5}{|c|}{ Length-class $(\mathrm{cm})$} & \multicolumn{2}{|c|}{ Combined lengths } \\
\hline & 50 & 57.5 & 65 & 72.5 & 80 & Eels & Fecundity \\
\hline \multicolumn{8}{|c|}{ Simulated production } \\
\hline Potential fecundity $\times 10^{9}$ & 79.59 & 240.87 & 692.86 & 478.84 & 320.54 & & $1,812.69$ \\
\hline \multicolumn{8}{|c|}{ Percentage of simulated production surviving } \\
\hline $60 \%$ survival per dam & 23.7 & 20.2 & 17.3 & 15.1 & 13.2 & 17.7 & 16.7 \\
\hline
\end{tabular}

survival by $1.0-1.4$ percentage points at the three survival rates (Table 2). This is because of the trade-off between the lower survival rate of larger length-classes and the exponential nature of the length-fecundity relationship. For example, at the mean survival rate of $80 \%$ per dam, the largest length-class represented $10 \%$ of production (by baseline condition), whereas it represented nearly $18 \%$ of potential population fecundity. However, that length-class represented only $15 \%$ of realized population fecundity.

Sensitivity analyses at the three survival rates showed that a small increase in population density up the drainage had the greatest positive effect on female survival to the sea and realized fecundity, except at the $60 \%$ survival rate, where a small increase in female length became most important in realized fecundity (Figure 3). At higher rates of survival, too, realized fecundity is sensitive to small changes in female length. Surprisingly, over-

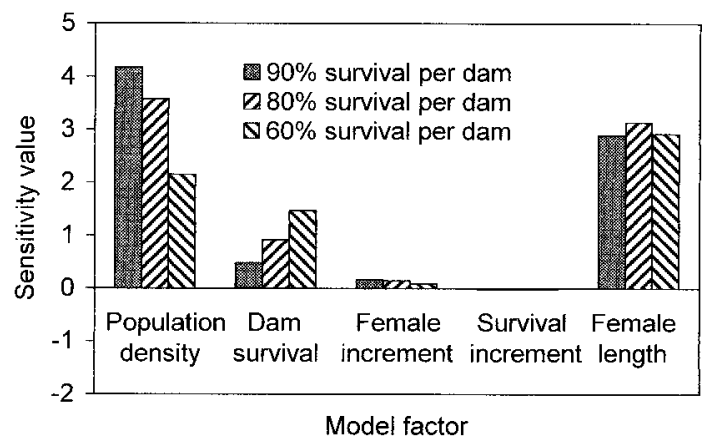

FIGURE 3.- Sensitivity of American eel realized fecundity (fecundity of the spawning population) for $5 \%$ changes in model variables at three rates of survival at dams in the Kennebec River basin. Sensitivities of dam survival and survival increments per length-class were calculated using the corresponding mortality rates and by reversing the signs of the sensitivities. all eel survival and realized fecundity are less sensitive to small changes in rate of survival at dams than to population density or female length. There are some variations when one considers individual length-classes, but trends are clear from examining the length-classes combined (Figure 3).

\section{Effect of Removal of Edwards Dam}

Edwards Dam, the lowermost dam on the main stem of the Kennebec River (Figure 1), ceased generating electricity in 1998 and was removed during 1999. To investigate the likely effects, the model was used with the same baseline conditions as already presented and the same three levels of survival per dam. First, Edwards Dam was considered as present but not generating electricity; that is, the mortality rate was zero, but population density was still decreased above the dam. Then, the dam was considered as removed.

Ceasing operation resulted in a simulated increase in overall survival of female American eels, compared with production under baseline conditions, of between 5.6 and $7.3 \%$, the greatest improvement occurring at the intermediate survival rate $(80 \%$ per dam; Figure $4 \mathrm{~A})$. Removing the dam increased production by about $0.9 \%$ but only increased survival by up to $0.6 \%$. Thus, overall survival increased $6.0-7.6 \%$, again with greatest improvement at the intermediate survival rate.

Ceasing operation resulted in an increase in overall survival of females compared with survival under baseline conditions, of between $8.9 \%$ and $31.6 \%$, the greatest improvement occurring at the lowest survival rate (60\% per dam). Removing the dam created less than a $1 \%$ increase in survival, and trends in realized fecundity were similar (Figure 4B). Although the effect of eliminating turbine mortality at a given dam would be realized at the next migration season, any increased production 

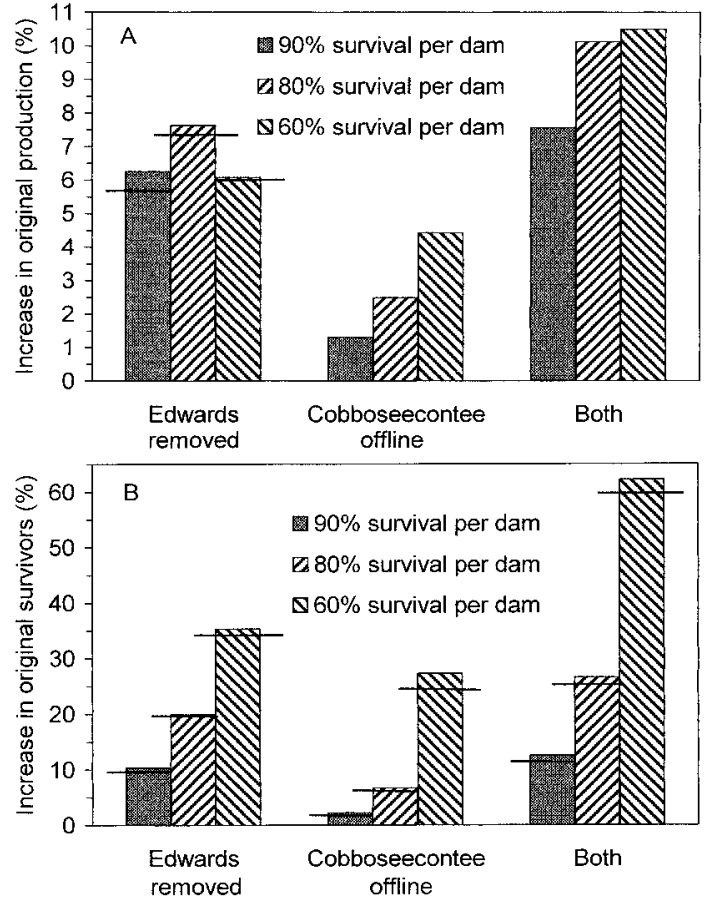

FIGURE 4.-(A) Increase in survival, as a percentage of production of female silver American eels, given three rates of survival at dams in the Kennebec River basin and three scenarios: Edwards Dam removed, the two dams on the Cobboseecontee Stream causing no mortality, and both conditions combined. Horizontal lines mark the percentages with Edwards Dam off line but still present. (B) Increase in survival as a percentage of original survival of female silver American eels (horizontal lines) and as a percentage of the original realized fecundity (fecundity of the spawning population; vertical bars), given three rates of survival at dams in the Kennebec River basin and three scenarios: Edwards dam removed, the two dams on the Cobboseecontee Stream causing no mortality, and both conditions combined.

from improved upstream passage would not be apparent for 15 years or so.

\section{Effect of New Mills and American Tissue Projects}

New Mills Dam on Cobbosseecontee Stream is in place, but power has not been generated there for several years; the American Tissue Dam just below it (Figure 1) has been operated in recent years under a protocol designed to allow downstream American eel passage during nights in autumn. In simulating these effects, it was assumed that downstream survival rates were $100 \%$ at these two dams, but because the dams were in place, population density decreased above them. The situations with Edwards Dam in full operation and removed were simulated. Otherwise, the model used the same baseline conditions and three levels of mortality.

Increasing survival to $100 \%$ at the two Cobboseecontee Stream projects and with Edwards Dam in operation, increased the survival of females for the overall Kennebec River drainage by $1.3-4.4 \%$ of production, and by $2.1-25.0 \%$ of baseline survival. Greatest improvement was at the lowest dam survival rate (Figure 4). With Edwards Dam removed as well, simulated survival increased by $7.6-10.5 \%$ of production and by 12.0 $59.4 \%$ of original survival over the conditions of full hydroelectric generation (Figure 4). Realized fecundity was slightly greater at the highest survival rate per dam and considerably greater at the lowest (Figure 4B).

\section{Effect of Water-Control Dams}

The approximately 73 water-control dams in the Kennebec River basin may hinder upstream passage of juvenile American eels. To examine the added effects of the water-control dams, six simulations were made assuming that population decrease upstream was $1 \%$ or $5 \%$ per water-control dam and that survival rates during downstream passage were 90,80 , or $60 \%$ per hydroelectric dam. Population decrease upstream was also $5 \%$ per hydroelectric dam. Other conditions were baseline.

Water-control dams had only a small impact on production or survival of American eels or on realized fecundity in these simulations for the Kennebec River. Production of eels and potential population fecundity and survival of eels and realized fecundity were greater than $99 \%$ and $96 \%$ of those without water-control dams at $1 \%$ and $5 \%$ population decrease per water-control dam, respectively. The small impact is because most of the water control dams are high in the drainage and provide minor eel production areas above them.

\section{Effect of Commercial Fishing Weirs}

Commercial harvest of silver American eels at the 15 weirs in the Kennebec River basin superimposes fishing mortality on hydroelectric mortality. To examine the added effect of weirs, six simulations were made that assumed survival rates of female eels were $25 \%$ or $5 \%$ per weir and were 90,80 , or $60 \%$ per hydroelectric dam. Because weirs are only allowed in streams during the fall fishing season, they were assumed not to affect population density or female proportion. Weirs were assumed to capture all length-classes of fe- 
TABLE 3.-Percentage changes in survival and realized fecundity (number of eggs in all surviving female spawners) of silver-phase female American eels by length-class at two rates of survival per weir and three mean rates of survival per hydroelectric dam in the Kennebec River basin with 15 weirs and 22 hydroelectric dams in operation. Values are percentages of the survival without weirs but with hydroelectric dams (Table 2).

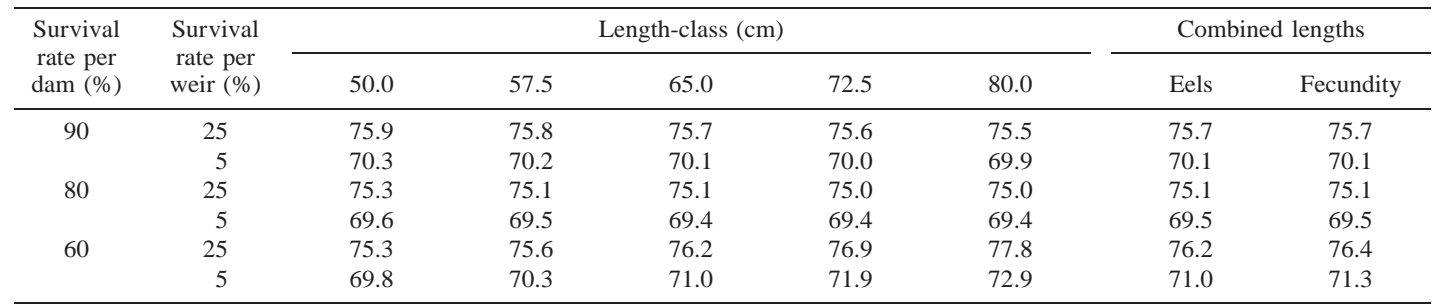

males equally. All 22 hydroelectric projects were assumed to have turbines operating.

At the weir survival rates of $25 \%$ and $5 \%$, the weirs reduced overall survival of American eels to about $75 \%$ and realized fecundity to about $70 \%$ of survival without weirs, regardless of hydroelectric dam survival rate (Table 3). Length-class of females made little difference in reduction in
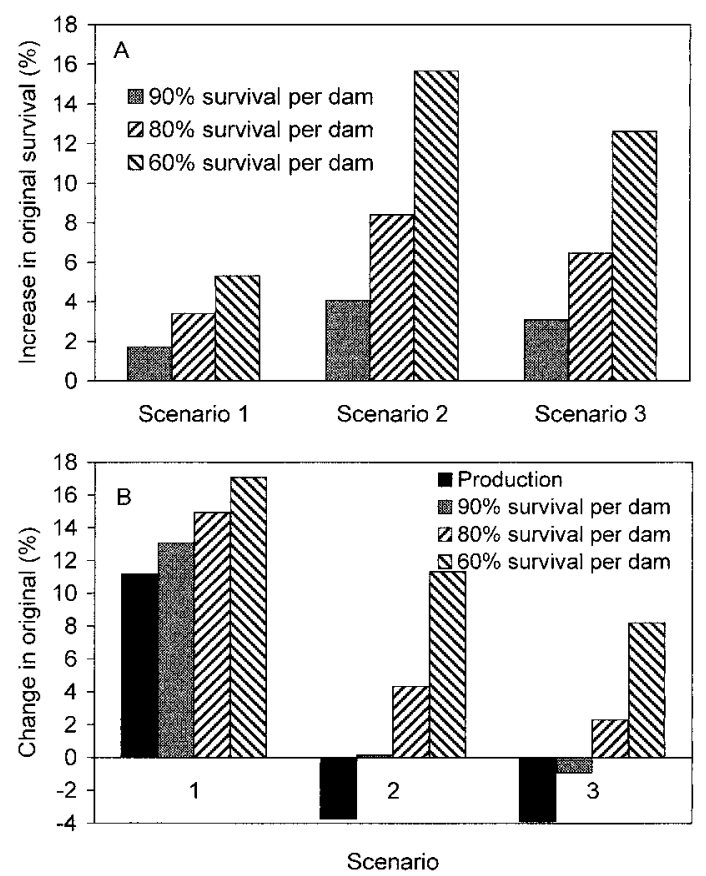

FIGURE 5.-(A) Increase in survival as a percentage of original survival (Figure 2) of female silver American eels, given three scenarios of increased production in lakes and ponds in the Kennebec River basin (see text descriptions) and three rates of survival at dams, when total basinwide production was adjusted to the original production (Table 2). (B) Change in production and survival as a percentage of original when basinwide production was not adjusted. survival at the two higher dam survival rates. At the lowest dam survival rate for both weir capture rates, survival of the longest length-class was about $2-3 \%$ less than the shortest length-class.

\section{Increased Proportion of Females in Lakes}

There is anecdotal evidence that lakes and ponds produce a much higher proportion of female silver American eels than do streams in Maine. Therefore, this effect was simulated in three scenarios: (1) by setting the proportion of females at 0.95 for the drainage area with the highest percentage of lake surface area, 0.85 for the next three highest, and 0.75 for the fifth highest (Table 1) and by leaving the proportions in other areas incremented as in previous simulations; (2) by setting the same five values but leaving the proportion at 0.50 for all other areas; and (3) by making the proportion of females proportional to the lake surface area percentage of each area, which ranged from 0.50 for areas with less than $0.1 \%$ lake area to 0.95 for the area with the greatest percentage $(17.4 \%$; Table 1). All 22 hydroelectric projects were assumed to be generating, and the usual three survival rates per dam were used. To facilitate comparisons, simulations were iterated by adjusting the sex ratio at the bottom of the basin until production by lengthclass and in total was the same as in the original simulations (Figure 2; Table 2). Also, simulations were made without adjusting the base sex ratio.

When production was equal, survival of females was greater in all cases than in original simulations, and percentage improvement increased with decreasing survival rate per dam, and increased from scenario 1 to 3 to 2 (Figure 5A). However, in no case was the improvement greater than $16 \%$ for survival of eels or in realized fecundity. When the base sex ratio was not adjusted, production was $11 \%$ greater in scenario 1 than in original simulations, but production was nearly $4 \%$ lower in 
TABLE 4.- Simulated production and survival of silver-phase female American eels and their potential population fecundity in the Kennebec River basin at three rates of upstream population decrease per hydroelectric dam and three rates of upstream proportional increase in females per hydroelectric dam. Survival date during downstream migration in all cases was $80 \%$ per dam. The upper half of the table assumes a $2.5 \%$ increase in proportion of females per hydroelectric dam; the lower half assumes a 5\% decrease in population density per hydroelectric dam. Survival percentages are equal for eels and fecundity within length-classes but differ when length-classes are combined.

\begin{tabular}{|c|c|c|c|c|c|c|c|c|}
\hline \multirow{2}{*}{$\begin{array}{l}\text { Rate of change } \\
\text { of model factor }\end{array}$} & \multirow{2}{*}{ Output category } & \multirow{2}{*}{\multicolumn{5}{|c|}{ Length-class $(\mathrm{cm})$}} & \multicolumn{2}{|c|}{ Combined lengths } \\
\hline & & & & & & & Fels & Fecun- \\
\hline \multicolumn{9}{|c|}{ Population density decrease } \\
\hline \multirow[t]{3}{*}{$5 \%$ per dam ${ }^{a}$} & Number of eels produced & 40,239 & 80,477 & 160,955 & 80,477 & 40,239 & 402,387 & \\
\hline & Potential fecundity $\times 10^{9}$ & 79.59 & 240.87 & 692.86 & 478.84 & 320.54 & & $1,812.69$ \\
\hline & Survival to sea $(\%)$ & 47.5 & 43.4 & 39.7 & 36.3 & 33.2 & 39.9 & 38.5 \\
\hline \multirow[t]{3}{*}{$15 \%$ per dam } & Number of eels produced & 24,615 & 49,228 & 98,453 & 49,228 & 24,615 & 246,139 & \\
\hline & Potential fecundity $\times 10^{9}$ & 48.68 & 147.34 & 423.81 & 292.90 & 196.08 & & $1,108.82$ \\
\hline & Survival to sea $(\%)$ & 52.3 & 48.3 & 44.9 & 41.6 & 38.7 & 45.1 & 43.7 \\
\hline \multirow[t]{3}{*}{$35 \%$ per dam } & Number of eels produced & 9,686 & 19,373 & 38,738 & 19,373 & 9,686 & 96,856 & \\
\hline & Potential fecundity $\times 10^{9}$ & 19.16 & 57.98 & 166.75 & 115.27 & 77.16 & & 436.2 \\
\hline & Survival to sea $(\%)$ & 65.8 & 62.8 & 59.9 & 57.3 & 54.8 & 60.0 & 59.0 \\
\hline \multicolumn{9}{|c|}{ Female proportional increase } \\
\hline \multirow[t]{3}{*}{$1.25 \%$ per dam } & Number of eels produced & 36,555 & 73,103 & 146,212 & 73,103 & 36,555 & 365,528 & \\
\hline & Potential fecundity $\times 10^{9}$ & 72.30 & 218.80 & 629.39 & 434.96 & 291.20 & & $1,646.65$ \\
\hline & Survival to sea $(\%)$ & 48.3 & 44.2 & 40.5 & 37.1 & 34.1 & 40.7 & 39.3 \\
\hline \multirow[t]{3}{*}{$2.5 \%$ per dam ${ }^{a}$} & Number of eels produced & 40,239 & 80,477 & 160,955 & 80,477 & 40,239 & 402,387 & \\
\hline & Potential fecundity $\times 10^{9}$ & 79.59 & 240.87 & 692.86 & 478.84 & 320.54 & & $1,812.69$ \\
\hline & Survival to sea $(\%)$ & 47.5 & 43.4 & 39.7 & 36.3 & 33.2 & 39.9 & 38.5 \\
\hline \multirow[t]{3}{*}{$5.0 \%$ per dam } & Number of eels produced & 47,610 & 95,219 & 190,439 & 95,219 & 47,610 & 476,097 & \\
\hline & Potential fecundity $\times 10^{9}$ & 94.16 & 284.99 & 819.77 & 566.55 & 379.26 & & $2,144.74$ \\
\hline & Survival to sea $(\%)$ & 46.3 & 42.1 & 38.3 & 34.9 & 31.8 & 38.6 & 37.1 \\
\hline
\end{tabular}

a Baseline condition as in Table 2 .

scenarios 2 and 3. Despite that, survival was up to $17 \%$ greater than that of the original simulations, except it decreased by about $1 \%$ in scenario 3 at the highest survival rate per dam (Figure 5B).

\section{Effects of Population Density and Proportion of Females}

In the earlier series of simulations on the effect of 22 dams, survival was sensitive to small changes in the decrease of population density moving up the basin (Figure 3). In contrast, small changes in sex ratio had little impact on survival of females. However, all of those simulations assumed only a small decrease in population density moving up the basin (5\% per dam passed) and a small increase in female proportion moving up the basin (2.5\% per dam).

Two sets of three simulations with sensitivity analyses were used to investigate whether results would be similar if population density decreased more rapidly or if the proportion of females increased less or more rapidly than in the earlier simulations. Initial conditions were mostly as described earlier with turbine survival set equally for all dams at $80 \%$. Exceptions were that in the first set of simulations, population density decreased by 5 (as earlier), 15, and $35 \%$ per dam. In the second set, female proportion increased 1.25, 2.5 (as earlier), and $5 \%$ per dam.

Obviously, decreased upstream population density directly decreased silver female American eel production, whereas increased upstream proportion of females directly increased silver female production. Decreasing population to $15 \%$ and then to $35 \%$ per dam resulted in a decrease of production of females for the river as a whole to $61 \%$ and $24 \%$ of the production at a $5 \%$ population decrease per dam (Table 4). However, survival of those produced increased from $40 \%$ to $45 \%$ to $60 \%$. This was because the population was now more concentrated in the lower part of the drainage with fewer dams to negotiate. Realized fecundity was about 1.0-1.4 percentage points lower than survival of females.

The large effect on production and survival of females and realized fecundity manifested by a small change in population density up the drainage was decreased as upstream population density decreased (Figure 6A). This was partly because the $\pm 5 \%$ change used in the sensitivity analysis was less in absolute terms and partly because the population was more concentrated in lower parts of 

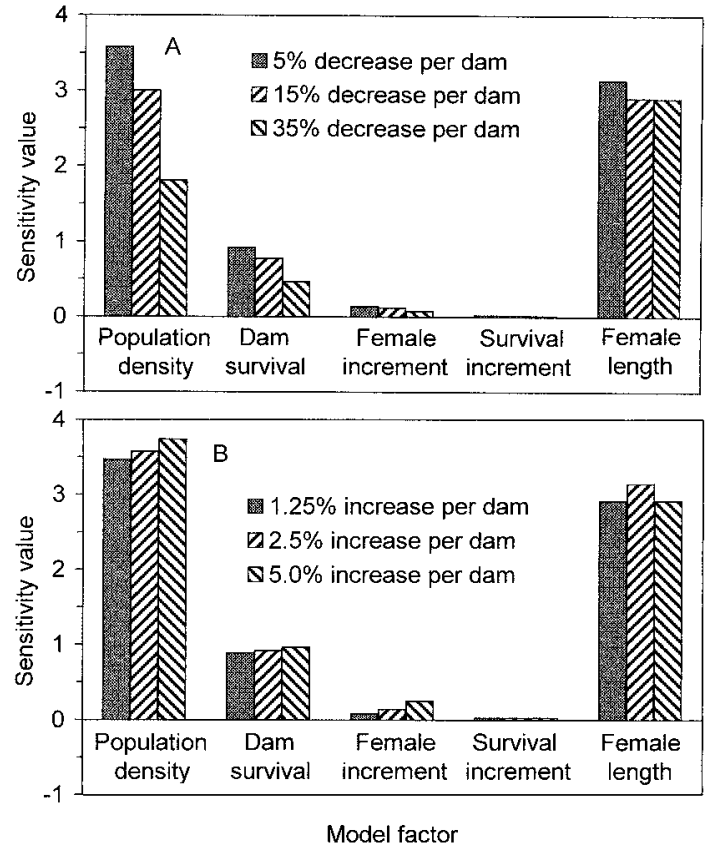

FIgURE 6.- Sensitivity of realized American eel population fecundity for $5 \%$ changes in model variables at $80 \%$ survival per dam in the Kennebec River basin for (A) three rates of population decrease upriver, at $2.5 \%$ increase in females per hydroelectric dam, and (B) three rates of proportional increase of females upriver, at 5\% population decrease per hydroelectric dam. Sensitivities of dam survival and survival increments per length-class were calculated using the corresponding mortality rates and by reversing the signs of the sensitivities.

the basin. At the intermediate and highest rates of decrease in population above each dam, small changes in female length became equally important and more important than small changes in population decrease in influencing realized fecundity. Survival rate per dam became less important as the population became more concentrated in lower portions of the basin.

Increasing the proportion of females by $1.25 \%$ instead of $2.5 \%$ per dam reduced production of females in the drainage by $9 \%$ but slightly increased survival rate and realized fecundity $(1 \%$; Table 4). Increasing the proportion by $5 \%$ instead of $2.5 \%$ per dam increased production by about $18 \%$ and reduced survival rate of American eels and realized fecundity by less than $2 \%$. However, absolute survival of American eels and realized fecundity were greater at the highest rate of upstream female increase. Sensitivity values changed little among the three rates of female proportion. Female proportion remained relatively unimpor- tant in influencing American eel survival and realized fecundity at all three base rates of change compared with population density and female length (Figure 6B).

\section{Discussion}

Note that the model was developed as an exploratory learning tool. It allowed me to ask "what-if" questions and compare results. The outputs of the model were simulations and are only useful to the extent that the assumptions are reasonable approximations of reality. Although the results of model simulations are presented as numbers of American eels and fecundity, the important features are the relative values from one simulation to another comparable simulation, differing only in the values of one variable.

There is one key implication from the application of the model as a learning tool to the Kennebec River basin. Improved knowledge of the biology of the American eel (population density, sex ratio, and female size by habitat type) is probably more important than improved knowledge of turbine mortality for implementing management practices to increase the reproductive potential of eels within a drainage. The actual magnitudes of the impacts of hydroelectric dams and commercial weirs calculated by the model are secondary at this time. However, improved biological knowledge should lead to improved quantitative estimates of impacts.

The cumulative impact of multiple hydroelectric projects within a river basin, as simulated, was substantial, even at high rates of survival through each project. The total survival in the basin was $40.5 \%$ of overall production when survival per dam was $80 \%$. This was reduced to $36.8 \%$ when only the production and survival above the lowermost dam were considered.

Sensitivity analyses under three sets of scenarios revealed that population density and length distribution of silver female American eels throughout the basin are important to production and realized fecundity. In the model, dam locations are used as computationally simple sites to decrease the population density (Smith and Saunders 1955; Levesque and Whitworth 1987; Smogor et al. 1995) and to increase the proportion of females up the drainage (Helfman et al. 1987), as may occur naturally or because of obstructions (White and Knights 1997). However, research on production and size distribution of females throughout a basin would be exceedingly valuable, especially because these important factors are very poorly understood. For example, Smogor et al. (1995) found a 
decline in density with distance from the sea for small- and medium-sized American eels but not for large eels, which probably contained a mixture of females and nearly mature males. Their medium category probably contained a mixture of immature and maturing males and immature females (Oliveira and McCleave 2000). The hypothesis of Helfman et al. (1987) that males are rare upriver of the estuary and females are distributed throughout a basin has never been carefully tested. Silver American eel runs from freshwater portions of rivers in the northern portion of their geographic range may be predominantly females (Smith and Saunders 1955; Bouillon and Haedrich 1985; Jessop 1987) or males (Krueger and Oliveira 1997; Oliveira and McCleave 2000).

There is an average 15-year or longer growth period between upstream migration of elvers and seaward migration of silver female American eels in this geographic region (Jessop 1987; Oliveira and McCleave 2000). There may be an inverse relation between population density and proportion of females (Svärdson 1976; Poole et al. 1990; Krueger and Oliveira 1999). There also may be a positive relation between area of ponds and lakes and proportion and size of females (Oliveira and McCleave 2001). The problem becomes complicated if increasing population density of young American eels decreases the proportion that become females (Poole et al. 1990; Krueger and Oliveira 1999). Learning about these relations and population density in general and for specific river basins may be key to conserving anguillids in basins with multiple hydroelectric projects.

That is particularly important because this modeling exercise leads to the interpretation that the benefits of getting more American eels upstream to grow and mature outweighs the effects of moderate increase in turbine survival. At low-head dams, as most are on the Kennebec River, providing for upstream passage of juvenile eels is likely to be easier and much less expensive than increasing turbine survival (reviewed in Richkus and Whalen 1999).

The Messalonskee Stream above the Oakland hydroelectric project has about 8,000 ha of lakes and ponds or approximately $17 \%$ of the overall drainage area. The Cobboseecontee Stream above New Mills has about 5,300 ha of lakes and ponds or nearly $10 \%$ of the overall drainage area. The commercial weir catch just above the Oakland project is composed almost entirely of females, and some of these are the largest American eels observed in Maine. The model results can be inter- preted to mean that high production of large females in these two streams low in the Kennebec drainage could contribute disproportionately to overall survival and realized fecundity. However, the magnitude of this potential effect depended on the modeled sex ratio in other parts of the basin, underscoring the need for determining production of female silver American eels by habitat type as well as distance from the sea.

The results of sensitivity analyses and of model runs manipulating mortality by turbine type (not presented) lead to the conclusion that attempting to estimate the rate of mortality at multiple hydroelectric sites would be a frustrating, resourceconsuming exercise of questionable value. Because of the low sensitivity of survival to small variation in mortality rate per dam (Figures 3,6) and the apparent site-, time-, and length-specific mortality rates, little predictive value is likely to result from the exercise. Again, this is not to suggest that downstream passage is unimportant, but rather mitigation plans might better be developed on the basis of improved knowledge of production and size distribution of female American eels in a basin. The simulations of the effects of removal of Edwards Dam or complete downstream passage on the Cobboseecontee Stream clearly support the view that reducing mortality to zero at dams low in a basin can improve overall survival from a basin dramatically. If the proportion of females were higher than as simulated in Figure 4 for the Cobboseecontee Stream, as incorporated in Figure 5 , the improvement would be even greater.

Simulations do not support the assertion by commercial weir operators that they have little impact because hydroelectric projects below them would kill the American eels even if the weirs were not in operation. Weirs that completely block streams catch nearly $100 \%$ of the silver American eels migrating downstream, except perhaps when a weir is flooded (F. Kircheis, Maine Department of Inland Fisheries and Wildlife, personal communication). The assumptions of $75 \%$ and $95 \%$ capture efficiency in the 15 weirs in the Kennebec River basin resulted in a simulated decrease in survival of $25-30 \%$ of silver female American eels. Removal of Edwards Dam and mitigation on the Cobboseecontee Stream probably means that the impact of weirs are greater than simulated. Clearly, hydroelectric projects are not the only significant source of anthropogenic mortality for silver American eels. 


\section{Acknowledgments}

Alexander Haro and Frederick Kircheis reviewed a draft of the manuscript; two anonymous reviewers provided useful comments for revision. Funds came from the Eel and Elver Management Fund administered by the Maine Department of Marine Resources.

\section{References}

Anonymous. 1994. The Maine Atlas and Gazetteer, 17th edition. Delorme Mapping Co. Freeport, Maine.

Anonymous. 1999. Fishery management plan for American eel. Atlantic States Marine Fisheries Commission, Washington, D.C.

Avise, J. C., G. S. Helfman, N. C. Saunders, and L. S. Hales. 1986. Mitochondrial DNA differentiation in North Atlantic eels: population genetic consequences of an unusual life history pattern. Proceedings of the National Academy of Sciences 83:43504354.

Barbin, G. P., and J. D. McCleave. 1997. Fecundity of the American eel Anguilla rostrata at $45^{\circ} \mathrm{N}$ in Maine, U.S.A. Journal of Fish Biology 51:840-847.

Berg, R. 1986. Fish passage through Kaplan turbines at a power plant on the River Neckar and subsequent eel injuries. Vie et Milieu 36:307-310.

Bouillon, D. R., and R. L. Haedrich. 1985. Growth of silver eels (Anguilla rostrata) in two areas of Newfoundland. Journal of Northwest Atlantic Fishery Science 6:95-100.

Burgman, M. A., S. Ferson, and H. R. Akçakaya. 1993. Risk assessment in conservation biology. Chapman and Hall, London.

De Leo, G. A., and M. Gatto. 1995. A size and agestructured model of the European eel (Anguilla anguilla L.). Canadian Journal of Fisheries and Aquatic Sciences 52:1351-1367.

Desrochers, D. 1995. Suivi de la migration de l'anguille d'Amérique (Anguilla rostrata) au Complexe Beauharnois, 1994. Report prepared by Milieu \& Associés for Hydro-Québec.

Fontaine, R. 1979. Drainage areas of surface water bodies of northern and southern Maine coastal river basins. U.S. Geological Survey, Augusta, Maine.

Fritz, J. J., editor. 1984. Small and mini hydropower systems: resource assessment and project feasibility. McGraw-Hill, New York.

Hadderingh, R. H., and H. D. Bakker. 1998. Fish mortality due to passage through hydroelectric power stations on the Meuse and Vecht rivers. Pages 315328 in M. Jungwirth, S. Schmutz and S. Weiss, editors. Fish migration and fish bypasses. Fishing News Books, Oxford.

Helfman, G. S., D. E. Facey, L. S. Hales, Jr. and E. L. Bozeman, Jr. 1987. Reproductive ecology of the American eel. Pages 42-56 in M. J. Dadswell, R. J. Klauda, C. M. Moffitt, R. L. Saunders, R. A. Rulifson, and J. E. Cooper. Common strategies of anadromous and catadromous fishes. American
Fisheries Society, Symposium 1, Bethesda, Maryland.

Heppel, S. S., L. B. Crowder, and D. T. Crouse. 1996. Models to evaluate headstarting as a management tool for long-lived turtles. Ecological Applications 6:556-565.

Hilborn, R., and M. Mangel. 1997. The ecological detective, confronting models with data. Princeton University Press. Princeton, New Jersey.

Jessop, B. M. 1987. Migrating American eels in Nova Scotia. Transactions of the American Fisheries Society 116:161-170.

Johnson, B. 1995. Applying computer simulation models as learning tools in fishery management. North American Journal of Fisheries Management 15: 736-747.

Krueger, W. H., and K. Oliveira. 1997. Sex, size, and gonad morphology of silver American eels Anguilla rostrata. Copeia 1997:415-420.

Krueger, W. H., and K. Oliveira. 1999. Evidence for environmental sex determination in the American eel, Anguilla rostrata. Environmental Biology of Fishes 55:381-389.

Levesque, J. R., and W. R. Whitworth. 1987. Age class distribution and size of American eel (Anguilla rostrata) in the Shetucket/Thames River, Connecticut. Journal of Freshwater Ecology 4:17-22.

Montén, E. 1985. Fish and turbines: fish injuries during passage through power station turbines. Vattenfall, Stockholm.

Normandeau Associates, and J. R. Skalski. 1998. Estimation of survival of American eel after passage through a turbine at the St. Lawrence-FDR power project, New York. Draft final report prepared by Normandeau Associates, Drumore, Pennsylvania for New York Power Authority, White Plains, New York.

Oliveira, K., and J. D. McCleave. 2000. Variation in population, and life history traits of the American eel, Anguilla rostrata, in four rivers in Maine. Environmental Biology of Fishes 59:141-151.

Oliveira, K., and J. D. McCleave. 2001. Regional variation, and the effect of habitat on sex distribution of American eels, Anguilla rostrata. Journal of Fish Biology 58:943-952.

Poole, W. R., J. D. Reynolds, and C. Moriarty. 1990. Observations on the silver eel migrations of the Burrishoole River system, Ireland, 1959 to 1988 . Internationale Revue der gesamten Hydrobiologie 75: 807-815.

Richkus, W., and K. Whalen. 1999. American eel (Anguilla rostrata) scoping study: a literature and data review of life history, stock status, population dynamics, and hydroelectric impacts. Report TR111873. EPRI. Palo Alto, California.

RMC. 1995. Report on studies to evaluate American eel passage. Prepared by RMC Environmental Services, Drumore, Pennsylvania for Allegheny Power Service Corp., Gettysburg, Pennsylvania. 
Smith, M. W., and J. W. Saunders. 1955. The American eel in certain fresh waters of the Maritime Provinces of Canada. Journal of the Fisheries Research Board of Canada 12:238-269.

Smogor, R. A., P. L. Angermeier, and C. K. Gaylord. 1995. Distribution and abundance of American eels in Virginia streams: tests of null models across spatial scales. Transactions of the American Fisheries Society 124:789-803.

Svärdson, G. 1976. The decline of the Baltic eel population. Institute of Freshwater Research, Drottningholm 55:136-143.

Travade, F., and M. Larinier. 1992. La migration de dévalaison: problèmes et dispositifs. Bulletin Fran- çaise de la Pêche et de la Pisciculture 326- 327: 165-176.

Vøllestad, L. A., and B. Jonsson. 1988. A 13-year study of the population dynamics and growth of the European eel Anguilla anguilla in a Norwegian river: evidence for density-dependent mortality, and development of a model for predicting yield. Journal of Animal Ecology 57:983-997.

White, E. M., and B. Knights. 1997. Dynamics of upstream migration of the European eel, Anguilla anguilla (L.), in the Rivers Severn and Avon, England, with special reference to the effects of man-made barriers. Fisheries Management and Ecology 4:311324. 